\title{
Assessment on Incompatibility of Health Problems between Obese and Non-Obese Girls Students of High School at Dhaka City in Bangladesh
}

\author{
Sharmin $\mathrm{SM}^{1}$, Yasmin $\mathrm{N}^{2}$, Khairujjaman $\mathbf{M}^{3}$, Seoty $\mathrm{NR}^{4}$, Islam $\mathrm{MR}^{5}$ and \\ Islam $\mathrm{MN}^{3 *}$ \\ ${ }^{1}$ Clinical Counselor, Dr. Jhumu Khan's Laser Medical Center, Bangladesh \\ ${ }^{2}$ Department of Public Health, State University of Bangladesh, Bangladesh \\ ${ }^{3}$ Department of Geography and Environment, Jahangirnagar University, Bangladesh \\ ${ }^{4}$ Department of Public Health, State University of Bangladesh, Bangladesh \\ ${ }^{5}$ Department of Gastroenterology, Patuaklhali Medical College, Bangladesh
}

Research Article

Volume 5 Issue 2

Received Date: August 10, 2021

Published Date: September 09, 2021

DOI: $10.23880 /$ phoa-16000188

*Corresponding author: Dr. Md. Nazrul Islam, Professor, Department of Geography and Environment, Jahangirnagar University, Savar, Dhaka-1342, Bangladesh, Email: nazrul_geo@juniv.edu

\section{Abstract}

This study analyzes whether there is any socio-economic, parental educational qualification and societal impact among obesity and non-obesity girl students. An epidemiological questionnaire survey has been conducted to find out the incompatibility of health problem girls obesity and non-obese in selected two girls high school in Dhaka city. The results revealed that there is a significance relationship between the obesity and socioeconomic status of the girl students' parents. The result shows that the surveyed girl students mean height was $61.55( \pm 2.92)$ inches. Among all body region head pain was highest $(47.06 \%)$ but it was not statistically significant $(\mathrm{p}>0.05)$. Neck pain was highest $(23.5 \%)$ those BMI was $\leq 25$. But it was statistically significant $(\mathrm{p}<0.05)$. Shoulder, Upper back and lower back pain were increases with their BMI subsequently. But it was not statistically significant $(p>0.05$ ). Hips pain was severe those BMI was $\leq 25$ but it was increases with BMI and it was statistically significant $(\mathrm{p}<0.05)$. Knee pain was also increases subsequently with their BMI but not statistically significant $(p>0.05)$. Ankle and feet Pain was rise according to their BMI and those region was statistically significant ( $<<0.05$ ). Here, $7.4 \%$ of students had blood pressure like medical condition. On the other hand, about $23.5 \%$ of students had breathing difficulty and another $28.2 \%$ of students suffering from others medical condition. Mean age was $11.88( \pm 0.940)$ years when menstruation starts. Almost all respondent's (67.1\%) menstruation starts between 11 to 12 years of age. Another $24.7 \%$ and $8.2 \%$ of respondent's menstruation starts 10 or below 10 years of age and 13 or above. Also some different problems was found among obese students so awareness can be raised regarding food habit and healthy life style to reduce this problems.

Keywords: Obesity; Food Habit; Socioeconomic Status; High School Girls; Bangladesh

Abbreviations: BMI: Body Mass Index; OECD: The Organization for Economic Co-operation and Development;
CDC: Centre for Diseases Control; NCD: Non-communicable Disease; WHO: World Health Organization. 


\section{Public Health Open Access}

\section{Introduction}

Obesity in high school life is one of the major public health problems in the recent time globally. During 2005, the prevalence of childhood overweight and obesity in high-income countries was $10.6 \%$ whereas in low-income countries, the prevalence was 5.2\% [1-6]. Due to a large population, Bangladesh faces a huge non-communicable health related problems as diseases-diabetes, cardiovascular disease, hypertension, stroke, chronic respiratory disease, cancer, communicable diseases as tuberculosis, HIV, tetanus, malaria, measles, rubella and leprosy etc [7-9]. On the other hand, more than one in two adults and nearly one in six children are overweight or obese in OECD countries [10-14]. The scientific evidences shows that the adult obesity rates are highest in the United States, Mexico, New Zealand and Hungary, while they are lowest in Japan and South Korea. But currently, Bangladesh is now experiencing the double burden of malnutrition, with the existence of both under nutrition and over nutrition, in urban cities [7,10-12,15]. Also, childhood overweight and obesity is a particular public health concern for Bangladesh because children who are overweight or obese have higher risk of becoming overweight or obese adults and overweight adults are at increased risk [7,11,12,16-18]. Obesity in children and adolescents is a major concern, not only because of health and social problems in the short-term, but also because there is a high health risk it may continue into adulthood and affect long-term health problems [8,9,19-24]. Especially, girls' high school-based nourishment instruction for high school girls and adolescents is a very important issue today, as girl growth, brain development and academic activities all depend largely on the quality and quantity of food consumed $[9,23,25]$.

According to the WHO, country profile of Bangladesh in 2016 , the physical inactivity was prevailing among $25.1 \%$ of population [1,13-16,26-33]. The recent trend of obesity among Bangladeshi young generation is very high. Due to the influence of western lifestyle, the internet, children are more likely to consume fast food and other junk foods. The impact of obesity is alarming early onset of NCDs and in some cases fatal incidents are occurring. NCD deaths are projected to increase by $15 \%$ globally between 2010 and 2020 [2-4,3438]. Although there are some studies of high school girl students in Bangladesh, most of them have been discussed about their food habit and about family unconsciousness in the obesity problems in their children. But in fact, in developing countries, obesity is directly linked to health related problems, socioeconomic status of the family, their attitude to the school going children, lack of awareness and strict monitoring of food processing and food habit $[7,12,17,18,39-43]$ Several studies results revealed that the girls students of body fat mass are very undue than many adults people in the country. Abdominal obesity among high school girls are shown to be an emerging issue $[8,9,44,45$,$] .$

The scientific epidemiological investigation shows that about one-third of obese pre-school children and about one-half of obese school age children become obese adult Lifestyle [13,25,26,45-48]. Especially, the socio-economic development have increased the obesity problems among the high school children especially girls in developing countries like Bangladesh, India and Pakistan etc [2-5,35,36,49-51]. However, it has recently been projected that the occurrence of obesity in teenage girl is increasing, most of these studies either high school or college representative samples from large cities which are contained with fast food without food values and quality [6,33,37,39,52-55]. Most of the literature on obesity relevant research indicated that the behavior of high school girls, their parent's socioeconomic standing, culture, and other influencing factors have also contributed to overweight and obesity of the high school girls $[19,20$ $22,26]$. In addition, several hormones imbalance in the brain, the gastrointestinal tract, and in fat cells themselves influence the girl metabolism, eating habits, and, eventually they gain weight [34, 39,40-43,50-52,56-58]. The medical science literature apparently noted that the most likely influencing factors to obesity are genetic, psychological, environmental, social and cultural effects $[8,9,23,24,29,35-37,46-48,59,60]$. Several studies suggest that now it is the high time for identifying the risk factors associated with overweight and obesity in high school girls would help to develop fitting mediations to decrease the future liability of obesity health related problems in Bangladesh.

\section{Aims and Objectives of this Study}

This study has been conducted with semi-structural questionnaire survey and observational strategically ways which is focused on the occurrence of health problem of obesity in high school girls of Dhaka city in Bangladesh. This epidemiological survey was conducted to find out the prevalence of health problem childhood obesity and nonobese girls in selected high school in Dhaka city. The main purpose of the study was to identity the health problems and analyze among obese and non-obese girl of selected high schools in Dhaka City.

\section{The More Specific Objective}

- To determine socio-demographic characteristics of obese and non-obese girl students of selected high schools in Dhaka City.

- To identity the health problems among obese and nonobese girl students of selected high schools in Dhaka City.

- To compare the health problems among the obese and nonobese girl students of selected high schools in Dhaka City. 


\section{Study Design and Methodology}

Body mass index (BMI) is the preferred method of expressing body fat percentile in groups $[7,13,17,18,46,61]$. To this date, three major reference charts are being utilized. These are the prominent Centre for Diseases Control (CDC) growth charts (CDC Growth Charts; 2000) [8,10-12,28,38,4648]. An epidemiological questionnaire survey has been conducted to find out the incompatibility of health problem girls obesity and non-obese in selected two girls high school in Dhaka city. Data were analyzed with SPSS computer based software. For all statistical test used in this study, statistically significant level set as $\mathrm{p} \leq .05$. The study place was Harin Dhara Girl's High school (case-A just symbolic name due to ethical issues of the research) and Bou Rani Girl's high School (case-B just symbolic name due to ethical issues of the research). The target population of this research was only girl students in class eight, nine and ten respectively.

\section{Sampling Techniques}

For conducting the questionnaire, it is applied the simple random sampling technique for selecting the respondents. The frame has been documented of girl students name and their class roll no. If any student were missing in their class during data collection, the survey conductor asked other students when that respondent was available at class in the alternative days. According to their information those respondents data was collected by systematically.

\section{Sample Size and Calculation}

To estimate proportion for cross-sectional study, the formula is Here,

$\mathrm{n}=$ desired sample

$\mathrm{z}=\mathrm{z}$-distribution at a given level of significance / confidence level (1.96)

$\mathrm{p}=0.33=33 \%$ (expected proportion of event or occurrence of the event)

$q=100-p=100-33=67$

$\mathrm{d}=$ allowable error ( 0.05 level of significance)

$$
n=\frac{z^{2} p q}{d^{2}}=339.75=340
$$

After statically calculation the desired sample size was 340 for the designed research.

\section{Data Collection Instrument}

A questionnaire were designed for this research which consisted of six parts with eighteen questions valid questions from the respondents as follows i.e. respondent's age structure, family composition, parents education, family's monthly income, family monthly expenditure, eating habit etc. Health problem questionnaire includes of any discomfort at different body regions and other discomfort related medical condition like breathing difficulties, hypertension due to obesity. Two types of questionnaire surveys have conducted in the study site. One was reproductive problem oriented questionnaire survey which results indicated that obese girls student main problems during menstrual period such as painful menstruation, irregular menstruation, bleeding or heavy flow etc. are severe than the non-obese girls student's. Similarly, another questionnaire survey has been conducted on the skin problem includes acanthosis nigricans, skin tag, hirsutism, acne valgaris are common of the obese girls students.

\section{Ethical consideration}

Approval from Ethical review committee of State University of Bangladesh was taken before conducting study. Permission form selected school authorities was taken (Though in this study was used the symbolic name of the school straighten the ethical issues of the research). Verbal and written consent form the respondents were taken prior to the interview. Informed consent form was translated into Bengali. Respondents had the right to refuse and withdraw her-self form study during data collecting period. Confidentiality and privacy of the respondents were maintained.

\section{Operational Definition}

It is noted that the term "obese" means children and adolescents who have a body mass index (BMI) at or above the $95^{\text {th }}$ percentile for their gender and age, while "overweight" describes those with a BMI at or above the $85^{\text {th }}$ but below the $95^{\text {th }}$ percentile. Non-obese means normal weight according to age, sex, height and weight $[29,30,14,31,32,52]$. BMI is a weight-to-height ratio, and is considered to be a reasonable reflection of body fat for most people. BMI is calculated by dividing body weight in kilograms by the square of height in meters $\left(\mathrm{kg} / \mathrm{m}^{2}\right)[2,34,36,50,40-43,49,55-57,59,60]$. Table 1 BMI index by dividing body weight in kilogram $(\mathrm{kg})$ by the square of height in meters $\left(\mathrm{kg} / \mathrm{m}^{2}\right)$.

\begin{tabular}{|c|c|c|}
\hline S.L. & BMI & Classification \\
\hline 1 & 18.5 to 24.9 & Normal weight \\
\hline 2 & 25 to 29.9 & Overweight \\
\hline 3 & $30+$ & Obesity \\
\hline 4 & $40+$ & Extreme obesity \\
\hline 5 & At or above the $85^{\text {th }}$ percentile & Overweight \\
\hline 6 & At or above the $95^{\text {th }}$ percentile & Obese \\
\hline
\end{tabular}

Table 1: BMI index by dividing body weight in kilogram $(\mathrm{kg})$ by the square of height in meters $\left(\mathrm{kg} / \mathrm{m}^{2}\right)$. 


\section{Results and Discussion}

Participation of this study who were selected purposively and each participant was provided with a consent form. For the analysis of this study, collecting different types of data have been analyzed and presented through different statistical methods. After completion of data analysis, the result was organized in the tabular form and figures as necessary respectively. The tables and figures are described below. The findings of the study are presented in the subsequent sections.

\section{Characteristics of the Respondents}

This study seeks to determine whether obesity is related to socioeconomic status and economic conditions of the respondents parents.Table-2 shows the distribution of students by age. The ages of the respondents were between 13 to 16 years and their mean age was $15.17( \pm 0.658)$ years. Among the 340 respondents most (68.5\%) were below 15 years of age and another $(31.5 \%)$ were above15 years of age.

\begin{tabular}{|c|c|c|}
\hline Age (Years) & Frequency & Percentage (\%) \\
\hline$<15$ & 233 & 68.5. \\
\hline$>15$ & 107 & 31.5 \\
\hline Total & $\mathbf{3 4 0}$ & $\mathbf{1 0 0 \%}$ \\
\hline
\end{tabular}

Table 2: Distribution of respondents by their age $(\mathrm{n}=340)$ (minimum age 13 years, Maximum age 16 years and Mean age 15.17 $( \pm 0.658)$ years).

\section{Parents Educational Qualifications of Respondents}

The number of obesity girl students is increasing day by day among many students in Dhaka, the capital of Bangladesh. The case schools are the girl high school in the middle of Dhaka city and many parents are educated but it is observed their children was facing the obesity health problems due to lack of proper guidance and management. The Figure 1 shows the distribution of student's by their mother's educational qualification. Among all respondent's mother $64.4 \%$ of graduate, HSC passed $23.8 \%, 10.3 \%$ SSC passed and only $1.5 \%$ mother had primary educational qualification.

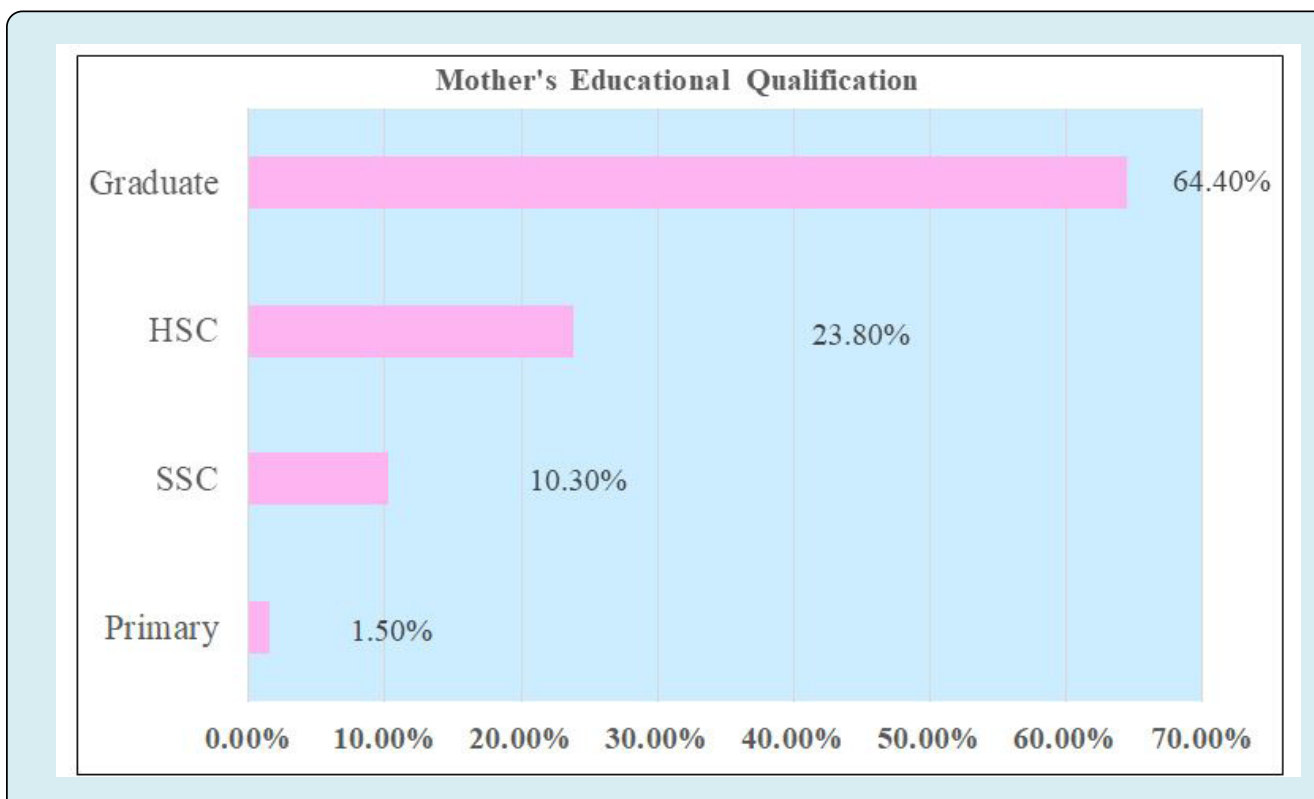

Figure 1: Distribution of respondents by their mother educational qualification $(n=340)$.

The study finding does not find any significant relationship (significant level of $\mathrm{p}<0.05$ ) with parent's educational qualification and obesity of the girl student at the selected high schools in Dhaka city. The survey results show that the distribution of student's by their father's educational qualification. Among all respondent's father $85.3 \%$ of graduate, HSC passed $10.3 \%$, SSC passed $2.9 \%$ and only $1.5 \%$ father had primary educational qualification. 


\section{Monthly Family Income of the Respondents}

Table 3 shows the distribution of students by their family income. Here, minimum family income was 30000 taka and maximum family income was 550000 taka. Their mean family income was $85264.71( \pm 78352.24)$ taka. Most of the families (88.9\%) income was less than 100000 taka. On the other hand only $5.9 \%$ and 5.65 family's income was 100000 to 200000 taka and more than 200000 taka.

\begin{tabular}{|c|c|c|}
\hline Family Income (BDT) & Frequency & Percentage (\%) \\
\hline$<100000$ & 301 & 88.5 \\
\hline $100000-200000$ & 20 & 5.9 \\
\hline$>200000$ & 19 & 5.6 \\
\hline Total & 340 & $100 \%$ \\
\hline
\end{tabular}

Table 3: Distribution of respondent's by their monthly Family Income ( $n=340)$.

\section{Correlation between Obesity and Respondent Health Discomfort}

Table 4 shows the distribution of discomfort among the girl obese and non-obese student's in their body region according to percentage. Among all respondent highest discomfort had present in head region (55.9\%). Another, neck pain was $30.9 \%$, in shoulder $22.1 \%$, in upper back region pain was $15.9 \%$, in lower back $20.6 \%$, in hips and knees region were $25 \%$ and $22.1 \%$ and in ankle and feet region pain were $11.8 \%$ and $4.4 \%$.

\begin{tabular}{|c|c|c|c|}
\hline \multirow{2}{*}{ Body Region of Obese Girl Students } & \multicolumn{2}{|c|}{ Discomfort/Pain } & \multirow{2}{*}{ Total } \\
\cline { 2 - 3 } & Yes & No & $340(100 \%)$ \\
\hline Head & $190(55.9 \%)$ & $150(44.1 \%)$ & $340(100 \%)$ \\
\hline Neck & $105(30.9 \%)$ & $235(59.1 \%)$ & $340(100 \%)$ \\
\hline Shoulder & $75(22.1 \%)$ & $265(77.9 \%)$ & $340(100 \%)$ \\
\hline Upper back & $54(15.9 \%)$ & $286(84.1 \%)$ & $340(100 \%)$ \\
\hline Lower back & $70(20.6 \%)$ & $270(79.4 \%)$ & $340(100 \%)$ \\
\hline Hips & $85(25 \%)$ & $255(75 \%)$ & $340(100 \%)$ \\
\hline Knees & $75(22.1 \%)$ & $265(77.9 \%)$ & $340(100 \%)$ \\
\hline Ankle & $40(11.8 \%)$ & $300(88.2 \%)$ & $340(100 \%)$ \\
\hline Feet & $15(4.4 \%)$ & $225(95.6 \%)$ & $300)$ \\
\hline
\end{tabular}

Table 4: Distribution of respondent's by pain in their different body region $(n=340)$.

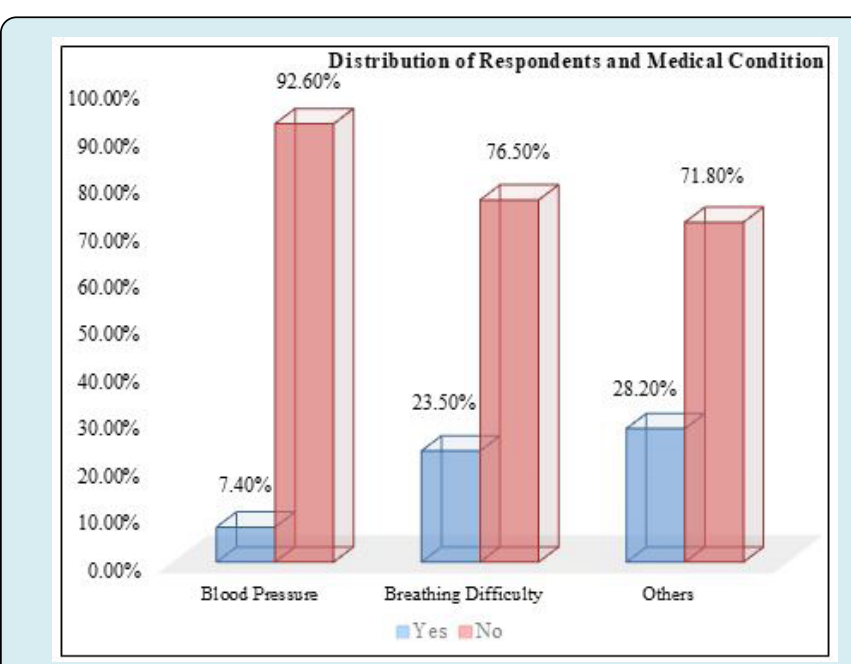

Figure 2: Distribution of respondent's percentage by their medical condition $(n=340)$.
Figure 2 shows distribution of respondents by their medical condition. Medical condition means Blood Pressure, Breathing Difficulty and Others such as Asthma etc. Here, $7.4 \%$ of students had blood pressure like medical condition. On the other hand, about $23.5 \%$ of students had breathing difficulty and another $28.2 \%$ of students suffering from others medical condition.

Table 5 shows the distribution of respondent's by their Systolic Blood Pressure. Here, I found student's minimum systolic blood pressure was $110 \mathrm{mmHg}$, maximum systolic blood pressure was $130 \mathrm{mmHg}$ and mean systolic blood Pressure was $117.84 \quad( \pm 6.423)$. Maximum student's systolic blood pressure was 120 or below $120(87.4 \%) .0 n$ the other side, $43 \%$ of systolic Blood pressure was more than 120 . 


\begin{tabular}{|c|c|c|}
\hline $\begin{array}{c}\text { Systolic Blood Pressure } \\
\text { (mmHg) }\end{array}$ & Frequency & $\begin{array}{c}\text { Percentage } \\
\text { (\%) }\end{array}$ \\
\hline$\leq 120$ & 297 & 87.4 \\
\hline$>120$ & 43 & 12.6 \\
\hline Total & 340 & $100 \%$ \\
\hline
\end{tabular}

Table 5: Distribution of respondent's by their systolic blood pressure $(\mathrm{n}=340)$. Minimum systolic blood pressure was 110 $\mathrm{mmHg}$, maximum Systolic blood pressure was $130 \mathrm{mmHg}$ and mean systolic blood pressure $117.84( \pm 6.423) \mathrm{mmHg}$.

Table 6 shows the distribution of high school girl student's age by their onset of menstruation in years. Here, the study results revealed that the respondent's age of onset of menstruation between 9 to 14 years. Mean age was $11.88( \pm 0.940)$ years when menstruation starts. Almost all respondent's (67.1\%) menstruation starts between 11 to 12 years of age. Another $24.7 \%$ and $8.2 \%$ of respondent's menstruation starts 10 or below 10 years of age and 13 or above.

\begin{tabular}{|c|c|c|}
\hline $\begin{array}{c}\text { Menstruation starts } \\
\text { (Years) }\end{array}$ & Frequency & $\begin{array}{c}\text { Percentage } \\
\text { (\%) }\end{array}$ \\
\hline$\leq 10$ & 28 & 8.2 \\
\hline $12-\mathrm{Nov}$ & 228 & 67.1 \\
\hline$\geq 13$ & 84 & 24.7 \\
\hline Total & 340 & $100 \%$ \\
\hline
\end{tabular}

Table 6: Distribution of respondent's age by their onset of menstruation in years $(n=340)$. Minimum age of onset of menstruation 9 years, Maximum age of onset of menstruation 14 years and Mean age of onset of menstruation 11.88 $( \pm 0.940)$ years.

The survey results also raveled that the distribution of respondent's by their height. The height of the respondents was found between 51 to 66 Inches. Minimum height was found 51 inches and maximum 66 inches. Mean height was $61.55( \pm 2.92)$ Inches.

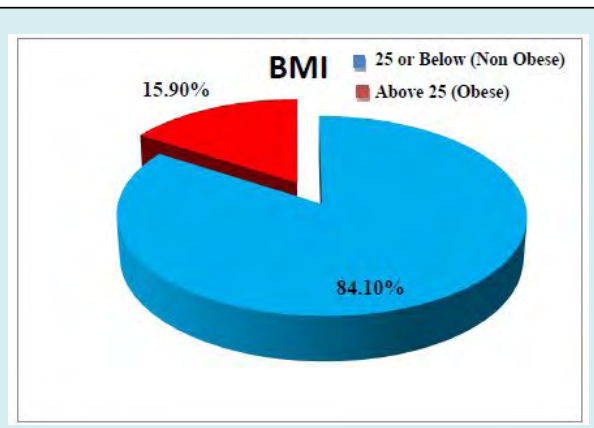

Figure 3: Distribution of Respondent's according to their BMI. It is observed that the $84.10 \%$ of respondents whose BMI was 25 or below. Another $15.9 \%$ of respondents BMI were above 25 .
The study results indicate that the obesity problem of the high school girl could be affected by Hirsutism which is a condition in women that results in excessive growth of dark or coarse hair in a male-like pattern face, chest and back. With hirsutism, extra hair growth often arises from excess male hormones (androgens), primarily testosterone. Also the Acanthosis nigricans could be made some negative impact which is a skin condition that causes a dark discoloration in body folds and creases. It typically affects the armpits, groin and neck. Acanthosis nigricans is a skin condition characterized by areas of dark, velvety discoloration in body folds and creases. Figure 4: distribution of respondent's according to their observational check list and it is found that the highest $16.2 \%$ was Hirsutism. Another $14.7 \%$ belongs to Acanthosis nigricans, Skin tag and Acne vulgaris was found $3.2 \%$ and $4.7 \%$ among all respondents. In Dhaka, Megacity population's growth rates are very high that's why ensuring the quality food supply and pure drinking water in the school students are the main challenges. In a results, many students took the junk first food at the lunch time which is enhancing the obesity problems in the high school students in Dhaka Megacity.

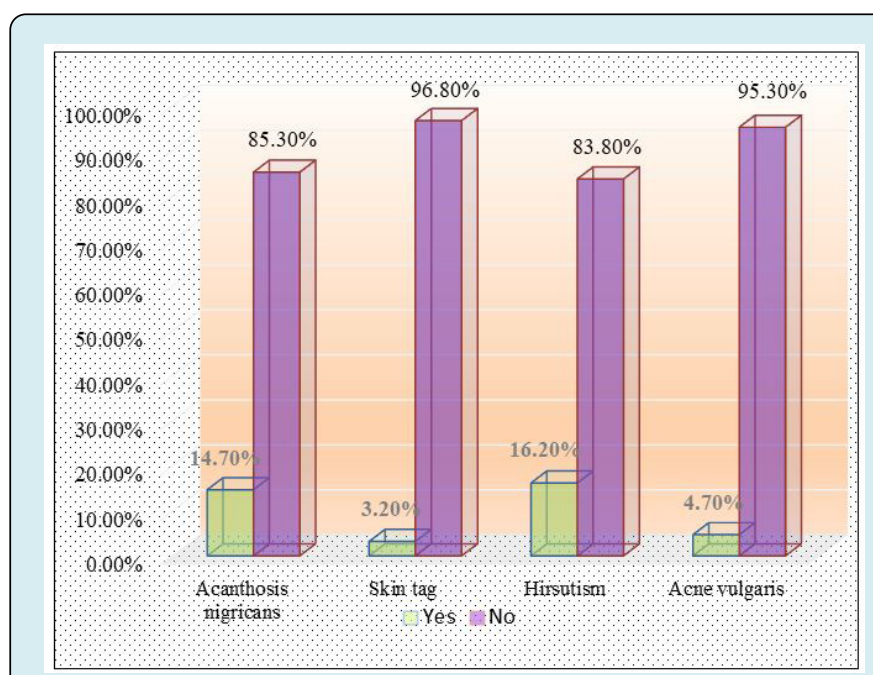

Figure 4: Distribution of respondent's according to their observational check list

\section{Incompatibility of Obese and Non-obese High School Girls}

This study compares the incompatibility of different medical health and physical problems of Obese and Nonobese High School Girls in twos elective high schools in Dhaka metropolis. According to the BMI policy, 54 girls out of 340 respondents are included in the Obesity Index and the remaining 286 girls are in the Non-Obese Index. Table 7 shows distribution of Respondent's Pain related medical condition in their body regions and BMI. Among all body region head pain was highest (47.06\%) but it was not statistically significant 
( $p>0.05$ ). Neck pain was highest (23.5\%) those BMI was $\leq 25$. But it was statistically significant $(\mathrm{p}<0.05)$. Shoulder, Upper back and lower back pain were increases with their BMI subsequently. But it was not statistically significant $(p>0.05)$. Hips pain was severe those BMI was $\leq 25$ but it was increases with BMI and it was statistically significant $(\mathrm{p}<0.05)$. Knee pain was also increases subsequently with their BMI but not statistically significant ( $p>0.05)$. Ankle (27.85) and feet Pain $(27.8 \%)$ was rise according to their BMI and those region was statistically significant $(\mathrm{p}<0.05)$.

\begin{tabular}{|c|c|c|c|c|}
\hline \multirow{2}{*}{\multicolumn{2}{|c|}{ Pain in different body region }} & \multicolumn{2}{|c|}{ BMI } & \multirow{3}{*}{ Test of significance } \\
\hline & & \multirow{2}{*}{$\begin{array}{c}\text { Non-obese }(\leq 25) \\
(n=286)\end{array}$} & \multirow{2}{*}{$\begin{array}{c}\text { Obese }(>25) \\
(n=54)\end{array}$} & \\
\hline & & & & \\
\hline \multirow{2}{*}{ Head } & Yes & $160(55.9 \%)$ & $30(55.6 \%)$ & \multirow{2}{*}{$\mathrm{p}=0.095$} \\
\hline & No & $126(44.1 \%)$ & $24(44.6 \%)$ & \\
\hline \multirow{2}{*}{ Neck } & Yes & $80(28 \%)$ & $25(46.3 \%)$ & \multirow{2}{*}{$\mathrm{p}=0.008^{*}$} \\
\hline & No & $206(72 \%)$ & $29(53.7 \%)$ & \\
\hline \multirow{2}{*}{ Shoulder } & Yes & $60(21 \%)$ & $15(27.8 \%)$ & \multirow{2}{*}{$\mathrm{p}=0.269$} \\
\hline & No & $226(79 \%)$ & $39(72.2 \%)$ & \\
\hline \multirow{2}{*}{ Upper back } & Yes & $44(15.4 \%)$ & $10(18.5 \%)$ & \multirow{2}{*}{$\mathrm{p}=0.563$} \\
\hline & No & $242(84.6 \%)$ & $44(81.5 \%)$ & \\
\hline \multirow{2}{*}{ Lower back } & Yes & $60(21 \%)$ & $10(18.5 \%)$ & \multirow{2}{*}{$\mathrm{p}=0.682$} \\
\hline & No & $226(79 \%)$ & $44(81.5 \%)$ & \\
\hline \multirow{2}{*}{ Hips/Thigh } & Yes & $60(21 \%)$ & $25(46.3 \%)$ & \multirow{2}{*}{$\mathrm{p}=0.005^{*}$} \\
\hline & No & $226(79 \%)$ & $29(53.7 \%)$ & \\
\hline \multirow{2}{*}{ Knees } & Yes & $60(21 \%)$ & $15(27.8 \%)$ & \multirow{2}{*}{$\mathrm{p}=0.269$} \\
\hline & No & $226(79 \%)$ & $39(72.2 \%)$ & \\
\hline \multirow{2}{*}{ Ankle } & Yes & $25(8.7 \%)$ & $15(27.8 \%)$ & \\
\hline & No & $261(91.3 \%)$ & $39(72.2 \%)$ & $\mathrm{p}=0.005^{*}$ \\
\hline \multirow{2}{*}{ Feet } & Yes & 0 & $15(27.8 \%)$ & \multirow{2}{*}{$\mathrm{p}=0.005^{*}$} \\
\hline & No & $286(100 \%)$ & $39(72.2 \%)$ & \\
\hline
\end{tabular}

Table 7: Association of Pain according to body region among obese school girls [*statistically significant $(\mathrm{p}<0.05)]$.

Table 8 shows distribution of Respondent's medical condition and BMI. Among all medical conditions Hypertension (HTN) was very high $27.8 \%$ for obese students and none-obese student's only $3.5 \%$ which was statistically significant $(\mathrm{p}<0.05)$ with BMI. Due to weight and other complications obese girl's students have also faced breathing difficulties.

\begin{tabular}{|c|c|c|c|c|}
\hline & & \multicolumn{2}{|c|}{ BMI } & \multirow[b]{2}{*}{ Test of significance } \\
\hline \multicolumn{2}{|c|}{ Medical condition } & Non-obese $\leq 25(n=286)$ & Obese $>25(n=54)$ & \\
\hline \multirow{2}{*}{ Hypertension (HTN) } & Yes & $10(3.5 \%))$ & $15(27.8 \%))$ & \multirow{2}{*}{$\mathrm{p}=0.005^{*}$} \\
\hline & No & $276(96.5 \%))$ & $39(72.2 \%))$ & \\
\hline \multirow{2}{*}{ Breathing difficulties } & Yes & $70(24.5 \%))$ & $10(18.5 \%))$ & \multirow{2}{*}{$\mathrm{p}=0.344$} \\
\hline & No & $216(75.5 \%))$ & $44(81.5 \%))$ & \\
\hline \multirow{2}{*}{ Others } & Yes & $81(28.3 \%))$ & $15(27.8 \%))$ & \multirow{2}{*}{$\mathrm{p}=0.935$} \\
\hline & No & $205(71.7 \%))$ & $39(72.2 \%))$ & \\
\hline
\end{tabular}

Table 8: Association of respondent's medical condition and BMI [*statistically significant $(\mathrm{p}<0.05)]$. 
Table 9 shows the distribution of Respondent's Observational checklist and BMI. Among all observational checklist acanthosis nigricans was $14 \%$ of those BMI was 25 or below 25 and other respondents whose BMI was more than 25 were having $18.5 \%$ of acanthosis nigricans. But it was not statistically significant ( $p>0.05)$.
The study results revealed that the Skin tag was 3.8\% who had BMI was 25 or below 25. But it was not statistically significant ( $p>0.05)$. Hirsutism was highest $27.8 \%$ who had BMI was more than 25. And it was statistically significant $(\mathrm{p}<0.05)$. Acne vulgaris was $3.8 \%$ who had BMI was 25 or below 25 and $9.3 \%$ of those BMI was more than 25 . And it was not statistically significant $(\mathrm{p}>0.05)$.

\begin{tabular}{|c|c|c|c|c|}
\hline & & \multicolumn{2}{|c|}{ BMI } & \multirow[b]{2}{*}{ Test of significance } \\
\hline \multicolumn{2}{|c|}{ Observational checklist } & $\begin{array}{c}\text { Non-obese } \leq 25 \\
(n=286)\end{array}$ & $\begin{array}{c}\text { Obese } \\
>25(n=54)\end{array}$ & \\
\hline \multirow{2}{*}{ Acanthosis nigricans } & Present & $40(14 \%)$ & $10(18.5 \%)$ & \multirow{2}{*}{$\mathrm{p}=0.388$} \\
\hline & Absent & $246(86 \%)$ & $44(81.5 \%)$ & \\
\hline \multirow{2}{*}{ Skin tag } & Present & $11(3.8 \%)$ & 0 & \multirow{2}{*}{$\mathrm{p}=0.143$} \\
\hline & Absent & $275(96.2 \%)$ & $54(100 \%)$ & \\
\hline \multirow{2}{*}{ Hirsutism } & Present & $40(14 \%)$ & $15(27.8 \%)$ & \multirow{2}{*}{$\mathrm{p}=0.012^{*}$} \\
\hline & Absent & $286(86 \%)$ & $39(72.2 \%)$ & \\
\hline \multirow{2}{*}{ Acne vulgaris } & Present & $11(3.8 \%)$ & $5(9.3 \%)$ & \multirow{2}{*}{$p=0.085$} \\
\hline & Absent & $275(96.2 \%)$ & $49(90.7 \%)$ & \\
\hline
\end{tabular}

Table 9: Association of observational checklist among obese and non-obese school girls $(n=340)$.

[*statistically significant $(\mathrm{p}<0.05)]$.

\section{Conclusion}

To compare the health problems of obese and nonobese girl students and to determine the socio demographic characteristics of obese and non-obese girl students of case study high schools in Dhaka City in Bangladesh have been analyzed in this study. Although this study analyzed the data of two girls' school in Dhaka metropolis of Bangladesh, but by the results of this research it was possible to predict the obesity rate of girls' high students, their physical problems and family status of the students and the level of overall awareness of the respondents and their parents. The study results revealed that the head pain was more common among obese students. Irregular menstruation, heavy menstruation and heavy blood flow was also common through obese students. Also, the neck, hips/thighs, ankle, feet pain, hypertension, hirsutism was statistically significant comparing with the BMI index. The study results indicated that the large scale study involving with different schools could be come to the more significant results of this kind of study. As different problems was found among obese students so awareness can be raised regarding food habit and healthy life style. This study could be pathways to realize the current obesity health problems of the high school girls and to build some policies for reducing this public health related obesity of high school girls in Bangladesh.

\section{Funding}

There is no funding support for this study

\section{Data Availability}

The datasets generated during and/or analyzed during the current study are available from the first and second author on reasonable request.

\section{Code Availability}

Not applicable

\section{Compliance with Ethical Standards}

There are no conflicts of interest in this study.

\section{References}

1. Dietz WH (1994) Critical periods in childhood for the development of obesity. Am J Clin Nutr 59(5): 955-959.

2. Karmakar P, Jahan N, Banik S, Das A, Rahman KA (2016) Food habits, obesity and nutritional knowledge among the university students in noakhali region of Bangladesh: a cross sectional study. J Food Nutr Disor 5: 4. 


\section{Public Health Open Access}

3. Biswas T, Islam A, Islam MS, Pervin S, Rawal LB (2017) Overweight and obesity among children and adolescents in Bangladesh: a systematic review and metaanalysis. Public Health 142: 94-101.

4. Hossain MS, Siddiqee MH, Ferdous S, Faruki M, Jahan R, et al. (2019) Is childhood overweight/obesity perceived as a health problem by mothers of preschool aged children in Bangladesh? A community level cross-sectional study. International journal of environmental research and public health 16(2): 202.

5. Khan MMA, Karim M, Islam AZ, Islam MR, Khan HT, Khalilullah MI (2019) Prevalence of overweight and obesity among adolescents in Bangladesh: do eating habits and physical activity have a gender differential effect? J Biosoc Sci 51(6): 843-856.

6. Ali N, Perveen R, Rahman S, Mahmood S, Rahman S, et al. (2018) Prevalence of hyperuricemia and the relationship between serum uric acid and obesity: a study on Bangladeshi adults. PLoS One 13(11): e0206850.

7. Sayeed MA, Mahtab H, Sayeed S, Begum T, Khanam PA, et al. (2010) Prevalence and risk factors of coronary heart disease in a rural population of Bangladesh. Ibrahim Medical College Journal 4(2): 37-43.

8. Reilly JJ (2005) Descriptive epidemiology and health consequences of childhood obesity. Best Pract Res Clin Endocrinol Metab 19(3): 327-341.

9. Mehta M, Bhasin SK, Agrawal K, Dwivedi S (2007) Obesity amongst affluent adolescent girls. The Indian J Pediatr 74(7): 619-622.

10. Bisai S, Khongsdier R, Bose $K$, Bhunia AK, Mahalanabis D, et al. (2010) Prevelance of overweight and obesity among Bengali adolescents in Midnapore town, West Bengal, India. Int J Current Res 10: 74-83.

11. Jesmin A, Yamamoto SS, Malik AA, Haque MA (2011) Prevalence and determinants of chronic malnutrition among preschool children: a cross-sectional study in Dhaka City, Bangladesh. Journal of health, population, and nutrition 29(5): 494-499.

12. Shenai S, Jose J (2019) Effectiveness of Nutrition Education and Lifestyle Interventions in Obesity. Indian Journal of Public Health Research \& Development 10(11).

13. Davis SP, Davis M, Northington L, Moll G, Kolar K (2002) Childhood obesity reduction by school based programs. Abnf Journal 13(6): 145-150.

14. Karnik S, Kanekar A (2012) Childhood obesity: a global public health crisis. Int J Prev Med 3(1): 1-7.

15. Mosha TCE, Fungo S (2010) Prevalence of overweight and obesity among children aged 6-12 years in Dodoma and Kinondoni Municipalities, Tanzania. Tanzan J Health Res 12(1): 6-16.

16. Rahman S, Islam MT, Alam DS (2014) Obesity and overweight in Bangladeshi children and adolescents: a scoping review. BMC public health 14(1): 1-8.

17. Akther M, Tabrez MS, Akther H, Alam ST, Sumon MH (2020) Body Mass Index and Waist Hip Ratio a Predictor of Hypertension of Adolescent Boys and Girls in a Metropolitan City in Bangladesh. Journal of Bangladesh College of Physicians and Surgeons 38(3): 110-115.

18. Rasul FB, Shawon MSR, Nazneen S, Hossain FB, Malik SS, et al. (2013) Do the dietary and lifestyle practices make the private medical students overweight: A crosssectional study in Bangladesh? J Biol Agri Health 3(2): 130-139.

19. Banik R, Naher S, Pervez S, Hossain MM (2020) Fast food consumption and obesity among urban college going adolescents in Bangladesh: A cross-sectional study. Obesity Medicine 17: 100161.

20. Jagadesan S, Harish R, Miranda P, Unnikrishnan R, Anjana RM, et al. (2014) Prevalence of overweight and obesity among school children and adolescents in Chennai. Indian pediatrics 51(7): 544-549.

21. Turchiano M, Sweat V, Fierman A, Convit A (2012) Obesity, metabolic syndrome, and insulin resistance in urban high school students of minority race/ethnicity. Arch Pediatr Adolesc Med 166(11): 1030-1036.

22. Taran SJ, Shashank O, Susmit K, Ravindra K (2016) Prevalence of obesity in school children and its association with parental obesity in central India. International Journal of Child and Adolescent Health 9(3): 377-385.

23. Lobstein T, Baur L, Uauy R (2004) Obesity in children and young people: a crisis in public health. Obes Rev 5(S1): 4-104.

24. Ikeda JP, Crawford PB, Woodward-Lopez G (2006) BMI screening in schools: helpful or harmful. Health Educ Res 21(6): 761-769.

25. McTigue KM, Garrett JM, Popkin BM (2002) The natural history of the development of obesity in a cohort of young US adults between 1981 and 1998. Ann Intern Med 136(12): 857-864.

26. Suzuki S, Ukiya T, Shibata C, Kawauchi Y, Ishii H, et al. 
(2020) Relationship between Obesity and Oral Health Behavior in Primary and Junior High School Students: A Cross-sectional Study. Bull Tokyo Dent Coll 61(3): 187193.

27. BK-Rauniyar, Sharmin-Jahan, Nusrat-Sultana, MashfiqulHasan, Atiqur-Rahman M, et al. (2018) Prevalence of Obesity is rising among Primary School Children in Dhaka City of Bangladesh. Diabetes and Obesity International Journal 3(3): 1-6.

28. Saha S, Zahid MK, Rasheed S (2011) The study of the level of knowledge, attitude, practices (KAP) as well as the effects of school environment on the nutritional status of children (7-12) coming from affluent families in the Dhaka City in Bangladesh. Bangladesh Journal of Nutrition 25: 31-48.

29. Deckelbaum RJ, Williams CL (2001) Childhood obesity: the health issue. Obes Res 9(S4): 239S-243S.

30. Kotani K, Nishida M, Yamashita S, Funahashi T, Fujioka S, et al.(1997) Two decades of annual medical examinations in Japanese obese children: do obese children grow into obese adults? Int J Obes Relat Metab Disord 21(10): 912921.

31. Drake AJ, Smith A, Betts PR, Crowne EC, Shield JPH (2002) Type 2 diabetes in obese white children. Arch Dis Child 86(3): 207-208.

32. Jabre P, Sikias P, Khater-Menassa B, Baddoura R, Awada $\mathrm{H}$ (2005) Overweight children in Beirut: prevalence estimates and characteristics. Child Care Health Dev 31(2): 159-165.

33. Hesketh K, Wake M, Waters E (2004) Body mass index and parent-reported self-esteem in elementary school children: evidence for a causal relationship. Int J Obes Relat Metab Disord 28(10): 1233-1237.

34. Zabeen B, Tayyeb S, Naz F, Ahmed F, Rahman M, et al. (2015) Prevalence of obesity and central obesity among adolescent girls in a district school in Bangladesh. Indian journal of endocrinology and metabolism 19(5): 649652.

35. Rahman S (2013) Obesity in junk food generation in Asia: A health time bomb that needs early defusing. South East Asia Journal of Public Health 3(1): 1-2.

36. Strugnell C, Mathrani S, Sollars L, Swinburn B, Copley V (2020) Variation in the Socioeconomic Gradient of Obesity by Ethnicity-England's National Child Measurement Programme. Obesity 28(10): 1951-1963.

37. Hoque ME, Doi SA, Mannan M, Long K, Niessen LW, et al. (2014) Prevalence of overweight and obesity among children and adolescents of the Indian subcontinent: a meta-analysis. Nutr Rev 72(8): 541-550.

38. Salahuddin $T$ (2021) Obesity is increasing among the younger generation in Bangladesh, Healthcare bulletin, The Daily Star, Dhaka, Bangladesh.

39. Bulbul T, Hoque M (2014) Prevalence of childhood obesity and overweight in Bangladesh: findings from a countrywide epidemiological study. BMC pediatrics 14(1): 1-8.

40. Alam MM, Hawlader MDH, Wahab A, Hossain MD, Nishat SA, et al. (2021) Determinants of overweight and obesity among urban school-going children and adolescents: a case-control study in Bangladesh. Int J Adolesc Med Health 33(1).

41. Bhuiyan MU, Zaman S, Ahmed T (2013) Risk factors associated with overweight and obesity among urban school children and adolescents in Bangladesh: a casecontrol study. BMC Pediatr 13(1): 72.

42. Rahman MN, Reza SA, Islam MA, Rahman A, Nath AK (2014) Prevalence of obesity and overweight among English medium school children of Dhaka City in Bangladesh. Journal of Environmental Science and Natural Resources 7(1): 63-67.

43. Sultana N, Afroz S, Tomalika N, Momtaz H, Kabir MH (2019) Prevalence of childhood obesity and undernutrition among urban school children in Bangladesh. Journal of biosocial science 51(2): 244-253.

44. Kurshed AAM, Rana MM, Khan S, Azad TMA, Begum J, etal. (2010) Dietaryintake, physical activities and nutritional status of adolescent girls in an urban population of Bangladesh. Ibrahim Medical College Journal 4(2): 7882.

45. Bose K, Bisai S, Mukhopadhyay A, Bhadra M (2007) Overweight and obesity among affluent Bengalee school girls of Lake Town, Kolkata, India. Matern Child Nutr 3(2): 141-145.

46. Gaeini A, Kashef M, Samadi A, Fallahi A (2011) Prevalence of underweight, overweight and obesity in preschool children of Tehran, Iran J Res Med Sci 16(6): 821-827.

47. Lindberg L, Danielsson P, Persson M, Marcus C, Hagman E (2020) Association of childhood obesity with risk of early all-cause and cause-specific mortality: A Swedish prospective cohort study. PLoS Med 17(3): e1003078.

48. Jain S, Pant B, Chopra H, Tiwari R (2010) Obesity among adolescents of affluent public schools in Meerut. Indian J 
Public Health 54(3): 158-160.

49. Latner JD, Stunkard AJ (2003) Getting worse: the stigmatization of obese children. Obes Res 11(3): 452456.

50. Langendijk G, Wellings S, Wyk VM, Thompson SJ, McComb J, et al. (2003) The prevalence of childhood obesity in primary school children in urban Khon Kaen, northeast Thailand. Asia Pac J Clin Nutr 12(1).

51. McCarthy HD, Ellis SM, Cole TJ (2003) Central overweight and obesity in British youth aged 11-16 years: cross sectional surveys of waist circumference. BMJ 326(7390): 624 .

52. Lawton J, Ahmad N, Hanna L, Douglas M, Hallowell N (2006) 'I can't do any serious exercise': barriers to physical activity amongst people of Pakistani and Indian origin with Type 2 diabetes. Health Educ Res 21(1): 4354.

53. Al Muktadir MH, Islam MA, Amin MN, Ghosh S, Siddiqui SA, et al. (2019) A Nutrition transition-Pattern IV: Leads Bangladeshi youth to the increasing prevalence of overweight and obesity. Diabetes Metab Syndr 13(3): 1943-1947.

54. Hassan MT, Das H, Banik S (2020) A cross-sectional study to determine the prevalence of overweight and obesity among Bangladeshi adolescents based on WHO, IOTF, and CDC cut-points. Obesity Medicine 19: 100285.
55. Banna MHA, Brazendale K, Hasan M, Khan MSI, Sayeed $A$, et al. (2020) Factors associated with overweight and obesity among Bangladeshi university students: a casecontrol study. J Am Coll Health 1-7.

56. Mistry SK, Puthussery S (2015) Risk factors of overweight and obesity in childhood and adolescence in South Asian countries: a systematic review of the evidence. Public health 129(3): 200-209.

57. Hossain MT, Luies SK, Biswas T (2020) Prevalence and factors associated with overweight and obesity among primary school children (9-14 years) in a selected area of Dhaka, Bangladesh: A cross-sectional study. Indian J Community Med 45(4): 429-434.

58. Mehmood Y, Al-Swailmi FK, Al-Enazi SA (2016) Frequency of obesity and comorbidities in medical students. Pak J Med Sci 32(6): 1528-1532.

59. Paul S, Solayman BP, Saha M, Hossain S (2015) Obesity and Hypertension in Students of Jahangirnagar University: Alarming Issues. Int J Public Health Sci 4(3): 164-171.

60. Gargari BP, Behzad MH, Ghassabpour S, Ayat A (2004) Prevalence of overweight and obesity among high-school girls in Tabriz, Iran, in 2001. Food Nutr Bull 25(3): 288291.

61. Chhatwal J, Verma M, Rair SK (2004) Obesity among pre-adolescent and adolescents of a developing country (India). Asia Pac J Clin Nutr 13(3): 231-235. 